\title{
B Cell Function in Patients with Chronic Pancreatitis and its Relation to Exocrine Pancreatic Function
}

\author{
B. Nyboe Andersen, T. Krarup', N. Thorsgaard Pedersen, O. K. Faber ${ }^{1}$, C. Hagen and H. Worning \\ Medical Department F, Glostrup Hospital, Glostrup and 'Hvidøre Hospital, Klampenborg, Denmark
}

\begin{abstract}
Summary. Exocrine pancreatic function was evaluated by a Lundh meal test and a secretin-cholecystokinin test in 16 patients with chronic pancreatitis. B cell function was assessed by measuring the concentration of C-peptide after stimulation with oral glucose and intravenous glucagon. The C-peptide response to intravenous glucagon and oral glucose was closely correlated $(r=0.88, p<0.01)$. Plasma C-peptide after glucagon was significantly correlated to the post-prandial concentration of lipase $(r=0.72, p<0.001)$, amylase $(r=0.64$, $p<0.05)$ and to amylase output $(r=0.64, p<0.05)$. Eight
\end{abstract}

out of nine patients treated with insulin had residual B cell function, but it diminished significantly with increasing duration of diabetes. We conclude that $\mathrm{B}$ cell function is correlated to pancreatic enzyme secretion and that patients with insulintreated diabetes secondary to chronic pancreatitis have a residual insulin secretion similar to that of patients with Type 1 (insulin-dependent) diabetes.

Key words: Chronic pancreatitis, B cell function, exocrine pancreatic function, C-peptide.
Attempts to correlate insulin secretion to exocrine pancreatic secretion in patients with chronic pancreatitis have revealed conflicting results (1-5). Serum insulin, however, might not be an ideal indicator of B cell function in chronic pancreatitis. This disease is commonly found together with alcoholism and cirrhosis of the liver [6] which is associated with hyperinsulinaemia due to a reduced hepatic extraction of insulin [7, 8]. Unlike insulin, C-peptide is not significantly extracted in the liver $[8,9]$, which makes estimation of peripheral C-peptide especially suited as a measurement of $B$ cell function in chronic alcoholism.

The aim of the present study was to investigate a possible connection between exocrine secretion and endocrine function as measured by plasma $\mathrm{C}$-peptide in patients with chronic pancreatitis. Furthermore, we studied the residual $B$ cell function in patients with insulin-dependent diabetes mellitus secondary to chronic pancreatitis.

\section{Material and Methods}

\section{Patients}

Sixteen patients with chronic pancreatitis were studied after informed consent. The diagnostic criteria were according to the Marseille classification [10]. No patient had previously been operated upon in the region of the stomach or pancreas and no one had a family history of diabetes. All had a normal renal function judged from serum creatinine. Clinical data are given in Table 1.

\section{Investigations}

All patients underwent the following investigations: (1) A Lundh meal test [11] measuring the post-prandial concentration of amylase and lipase. (2) Secretin-cholecystokinin test: a double lumen Eynard tube was placed in the distal part of the duodenum under fluoroscopic control, and ${ }^{57} \mathrm{Co}$-Vitamin $\mathrm{B}_{12}$ (Amersham International, UK) was constantly infused in order to estimate recovery. After 30 min of basal sampling, secretin (1 Clinical Unit $\mathrm{kg}^{-1} \cdot \mathrm{h}^{-1}$ ) and cholecystokinin (1 Ivy Dog Unit $\cdot \mathrm{kg}^{-1} \cdot \mathrm{h}^{-1}$ ) (Karolinska Institute, Stockholm, Sweden) were given IV for $1 \mathrm{~h}$. The outputs of amylase and bicarbonate during the last $30 \mathrm{~min}$ of the test were used as an expression of pancreatic secretion. The test was succesful in only 12 patients. (3) All patients were examined for faecal fat excretion and pancreatic calcification. (4) A percutaneous liver biopsy was performed for clinical reasons in six patients (Table 1). (5) Patients without overt diabetes (fasting blood glucose $>7.0 \mathrm{mmol} / \mathrm{l}$ ) had an oral glucose tolerance test with a load of $1.75 \mathrm{~g}$ glucose $/ \mathrm{kg}$ ideal body weight. Venous blood was sampled before and at $30 \mathrm{~min}$ intervals during the test and the concentrations of glucose and C-peptide in plasma were measured. (6) Glucagon-Cpeptide test: after an overnight fast an IV bolus injection of $1 \mathrm{mg}$ glucagon (Novo, Copenhagen, Denmark) was given, and blood sampled at $-15,0,2,4,6,8,10,15$ and $20 \mathrm{~min}$ [12]. Plasma C-peptide was measured in all samples using antiserum $\mathrm{M}_{1230}$ [13] as described by Heding [14]. B cell function was considered present if plasma C-peptide levels were equal to or exceeded $0.06 \mathrm{pmol} / \mathrm{m}$ ] [12]. Intra- and interassay variations for the assay were $3.2 \%$ and $9.6 \%$, respectively [13].

\section{Statistics}

Spearman's rank correlation test, linear regression and the MannWhitney U-test were used. The level of significance was 0.05 . 
Table 1. Clinical findings in 16 patients with chronic pancreatitis

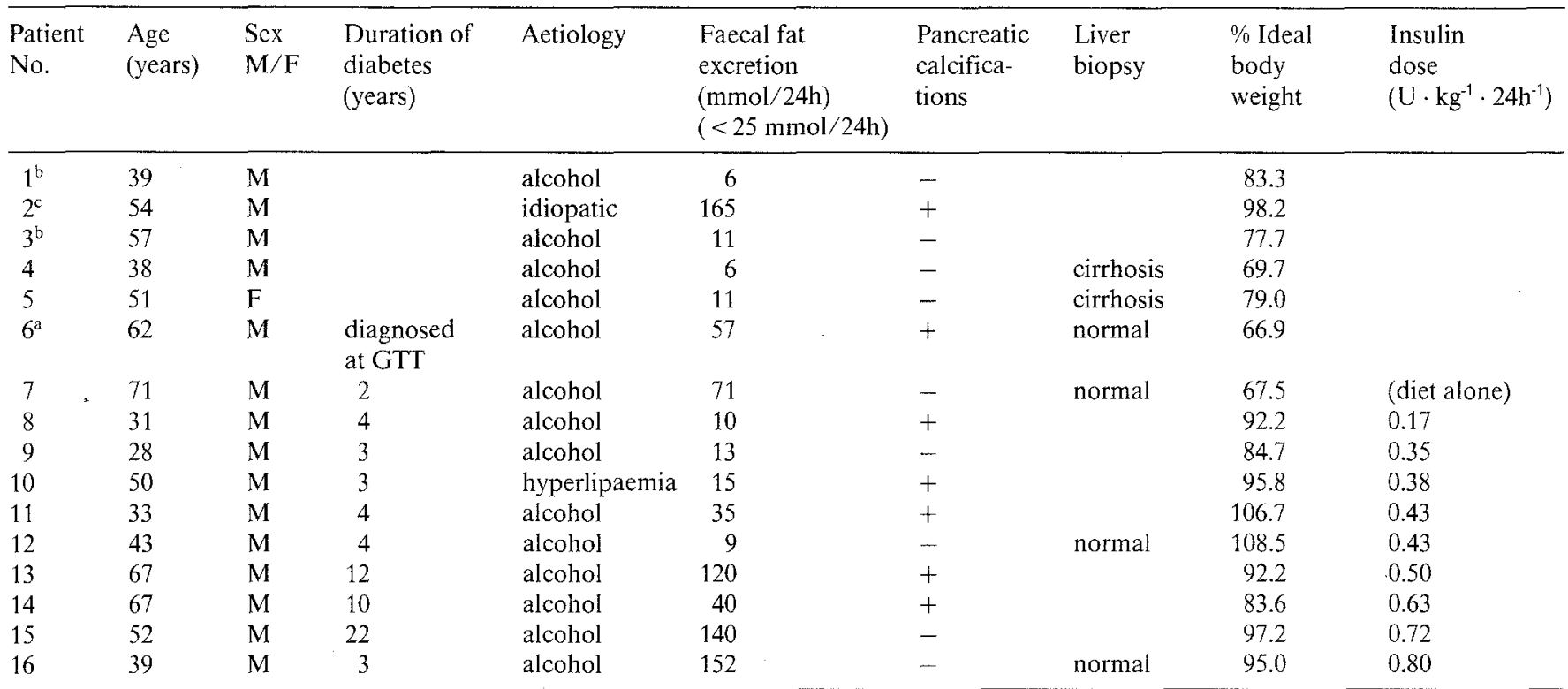

a Died 9 months after this investigation in an extremely malnurished state, and could be managed without insulin; ${ }^{b}$ Developed insulin-dependent diabetes within one year after the investigation; ${ }^{c}$ Continued to have normal weight and no evidence of diabetes one year after the investigation

$\mathrm{GTT}=$ glucose tolerance test

Table 2. Exocrine and endocrine function in 16 patients with chronic pancreatitis

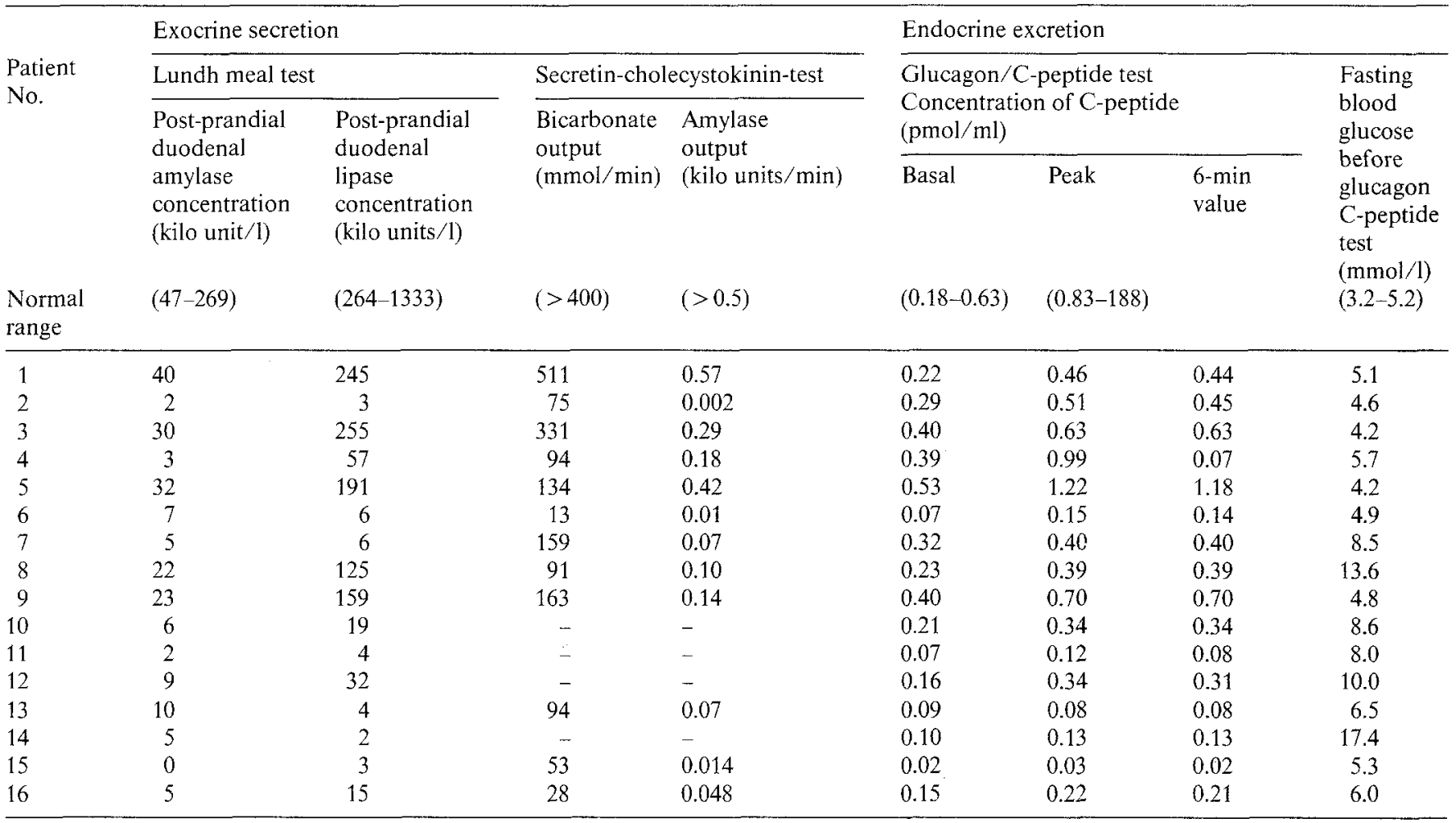

\section{Resuits}

The peak concentration of C-peptide after stimulation with glucagon and oral glucose was closely correlated $(r=0.88, p<0.01 ;$ Fig. 1$)$. The highest concentration of C-peptide occurred $6 \mathrm{~min}$ after the injection of gluca- gon. Furthermore, the peak and 6-min values were almost identical in individual patients (Table 2). The basal and peak concentration of C-peptide were closely dependent ( $r=0.94, p<0.001$; Table 2$)$.

There was a significant correlation between pancreatic enzyme secretion and the peak concentration of 


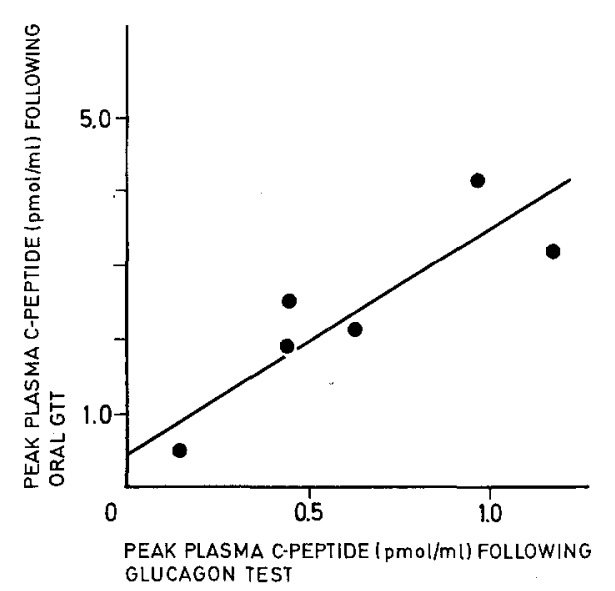

Fig. 1. The correlation between peak plasma C-peptide stimulated with oral glucose and IV glucagon. GTT = glucose tolerance test

C-peptide, but no clear correlation was demonstrated between bicarbonate secretion and $\mathrm{B}$ cell function (Tables 2 and 3). Patients with steatorrhoea had a significantly lower peak concentration of C-peptide (median value: $0.14 \mathrm{pmol} / \mathrm{ml}, p<0.01$ ) than patients without steatorrhoea (median value: $0.55 \mathrm{pmol} / \mathrm{ml}$ ). B cell function, however, was not significantly lower in patients with pancreatic calcifications compared with patients without $(p<0.1)$.

Eleven patients had diabetes, but there was a certain overlap in the concentration of C-peptide between diabetic and non-diabetic patients (Table 2). The insulin dose was inversely correlated to the glucagon stimulated C-peptide concentration $(r=-0.74, p<0.05)$. Only one of the nine patients treated with insulin had no detectable $\mathrm{B}$ cell function (Table 2). The insulin secretory capacity, as measured by the peak $\mathrm{C}$-peptide concentration after glucagon, diminished with increasing duration of diabetes $(r=-0.61, p=0.05)$. The same was found when considering only patients on insulin treatment $(r=-0.69, p<0.05)$.

\section{Discussion}

By measuring $\mathrm{C}$-peptide levels, we could conclude that the amount of insulin released by the $\mathrm{B}$ cells was significantly correlated to the excretion of pancreatic enzymes, and that this also holds true in patients treated with insulin who have been excluded from previous studies $(2,4,5)$. This association with exocrine function was also substantiated by the fact that our patients with steatorrhoea had a lower C-peptide secretion than those patients with a lesser degree of exocrine impairment. Such a correlation between C-peptide and exocrine secretion is not limited to patients with chronic pancreatitis, as a similar association has been demonstrated by Frier et al. [15] in Type 1 diabetes.

As in patients without chronic pancreatitis, oral glucose was a more potent stimulus to B cell secretion than
Table 3. Correlation between exocrine pancreatic secretion and B cell function measured as the peak concentration of C-peptide after stimulation with intravenous glucagon

\begin{tabular}{|c|c|c|c|}
\hline & & \multicolumn{2}{|c|}{$\mathrm{B}$ cell function } \\
\hline & & $r$ & $p$ \\
\hline \multirow[t]{2}{*}{$\begin{array}{l}\text { Lundh meal } \\
\text { test }(n=16)\end{array}$} & $\begin{array}{l}\text { Lipase } \\
\text { concentration }\end{array}$ & 0.72 & $<0.001$ \\
\hline & $\begin{array}{l}\text { Amylase } \\
\text { concentration }\end{array}$ & 0.46 & $<0.05$ \\
\hline \multirow{2}{*}{$\begin{array}{l}\text { Secretin- } \\
\text { cholecystokinin } \\
\text { test }(n=12)\end{array}$} & $\begin{array}{l}\text { Amylase } \\
\text { output }\end{array}$ & 0.64 & $<0.05$ \\
\hline & $\begin{array}{l}\text { Bicarbonate } \\
\text { output }\end{array}$ & 0.57 & $=0.06$ \\
\hline
\end{tabular}

intravenous glucagon, but the peak C-peptide concentrations after glucagon and oral glucose were closely correlated, indicating that the glucagon test can be used in patients with chronic pancreatitis.

Our findings indicate that B cell function is similar in diabetes secondary to chronic pancreatitis compared with Type 1 diabetic subjects. The peak concentration of C-peptide occurred at 6 min after glucagon as in Type 1 diabetes [12] and not after $10 \mathrm{~min}$ as among normal subjects [12]. Patients with chronic pancreatitis treated with insulin had residual $\mathrm{B}$ cell function for the first years after the onset of diabetes, and the residual B cell function declined with increasing duration of diabetes, as in Type 1 diabetic subjects [16]. This suggests that $\mathrm{B}$ cell function will finally disappear also in patients with chronic pancreatitis.

Patients with a post-stimulatory concentration of Cpeptide below $0.60 \mathrm{pmol} / \mathrm{ml}$ will normally require insulin [17]. Four of our patients had C-peptide concentrations below that level, but could be managed without insulin. This is an apparent difference between Type 1 diabetes and diabetes secondary to chronic pancreatitis. A low food intake, steatorrhoea and malnutrition might explain why such patients can avoid insulin treatment despite very limited endogenous insulin secretion. The glucagon-C-peptide test might thus be of limited use in predicting whether patients with chronic pancreatitis can be managed without insulin.

In Type 1 diabetes, patients with endogenous insulin secretion have a better degree of metabolic control and may be better protected against severe ketoacidosis, than patients without $\mathrm{B}$ cell function [18, 19]. This has particular relevance to the surgical treatment of patients with chronic pancreatitis. Partial pancreatectomy is likely to worsen B cell function, subtotal pancreatectomy is often associated with diabetes being difficult to control [20] and total pancreatectomy will result in permanent loss of $\mathrm{B}$ cell function. Our finding of a preserved B cell function in insulin-treated diabetes secondary to chronic pancreatitis, at least for the first years 
after the onset of diabetes, suggests that the degree of $B$ cell function should be taken into consideration before surgery of the pancreas.

\section{References}

1. Kalk WJ, Vinik Al, Bank S, Buchanan KD, Keller P, Jackson WPV (1974) Glucagon response to arginine in chronic pancreatitis. Diabetes 23: 257-263

2. Ohneda A, Kai Y, Ishi S, Matsuda K, Horigome K, Maruhama Y, Takebe T, Yamagata S (1976) Insulin and glucagon response in patients with chronic pancreatitis. Tohoku J Exp Med 120: 287-298

3. Peters N, Dick AP, Hales CN, Orrell PH, Sarner M (1966) Exocrine and endocrine pancreatic function in diabetes mellitus and chronic pancreatitis. Gut 7:277-281

4. Deckert T, Kølendorf K, Persson I, Worning H (1972) Insulin secretion after tolbutamide and after secretin in patients with pancreatic disease. Acta Med Scand 192: 465-470

5. Kalk WJ, Vinik AI, Jackson WPV, Bank S (1979) Insulin secretion and pancreatic exocrine function in patients with chronic pancreatitis. Diabetologia 16:355-358

6. Dutta SK, Holrahan S, Iber FL (1978) Associated liver disease in alcoholic pancreatitis. Dig Dis 23: 618-622

7. Johnston DG, Alberti KGMM, Faber OK, Binder C, Wright R (1977) Hyperinsulinism of hepatic cirrhosis. Diminished degradation or hypersecretion. Lancet I: 10-12

8. Kühl C, Faber OK, Hornnes P, Jensen SL (1978) C-peptide metabolism and the liver. Diabetes 27-1: 197-200

9. Stoll RW, Tauber JL, Menahan LA, Williams RH (1970) Clearance of porcine insulin, proinsulin and connecting peptide by the isolated liver. Proc Soc Exp Biol Med 133: 894-896

10. Perrier CV (1964) Symposium on the etiology and pathological anatomy of clinical pancreatitis. Marseille 1963. Am J Dig Dis 9: $371-376$

11. Worning H, Müllertz S (1966) PH and pancreatic enzymes in the human duodenum during digestion of a standard meal. Scand $J$ Gastroent 1: 268-283
12. Faber OK, Regeur L, Lauritzen T, Binder C (1979) The glucagon/ C-peptide test in the evaluation of beta-cell function. Proc Symposium on proinsulin, insulin and C-peptide Tokushima 1978. Excerpta Med Int Congr Ser 468: 205-210

13. Faber OK, Markussen J, Naithani UK, Binder C (1976) Production of antisera to synthetic benzyloxy-carbonyl-C-peptide of human proinsulin. Hoppe Seylers Z Physiol Chem 357: 751-757

14. Heding LG (1975) Radioimmunological determination of human C-peptide in serum. Diabetologia 11: 541-548

15. Frier BM, Faber OK, Binder C, Elliott HL (1978) The effect of residual insulin secretion on exocrine pancreatic function in juvenile-onset diabetes mellitus. Diabetologia 14: 301-304

16. Hendriksen C, Faber OK, Drejer J, Binder C (1977) Prevalence of residual beta-cell function in insulin treated diabetics evaluated by plasma C-peptide response to intravenous glucagon. Diabetologia 13: $615-619$

17. Madsbad S, Krarup T, McNair P, Christiansen C, Faber OK, Transbøl I, Binder C (1981) Practical clinical value of the C-peptide response to glucagon stimulation in the choice of treatment in diabetes mellitus. Acta Med Scand 210: 153-156

18. Madsbad S, Alberti KGMM, Binder C, Burrin JM, Faber OK, Krarup $T$, Regeur L (1979) Role of residual insulin secretion in protecting against severe ketoacidosis in insulin-dependent diabetes. Br Med J 2: 1257-1259

19. Madsbad S, McNair P, Faber OK, Binder C, Christiansen C, Transbøl I (1980) Beta-cell function and metabolic control in insulin treated diabetics. Acta Endocrinol 93: 196-200

20. Frey CF, Child CG, Fry W (1976) Pancreatectomy for chronic pancreatitis. Ann Surg 184: 403-414

Received: 16 October 1981

and in revised form: 21 April 1982

B. Nyboe Andersen, M.D.

Medical Department $F$

Glostrup Hospital

DK-2600 Glostrup, Denmark 